no eggs of trichuris. The only information on the occurrence of this parasite in the U.K. is from the returns made to the Public Health Laboratory Service. The number reported in 1969 was 1,218 and in 1970 was 1,132 (P.H.L.S., personal communication, 1971). However, the examination of stool specimens for helminth ova is not a routine procedure in many laboratories.

A survey of intestinal parasites in 3,855 immigrant children (Thompson et al. 1972) showed that about $14 \%$ harboured $T$. trichiura. In children from Hong Kong and the West Indies the incidences were over $70 \%$.

The cure rates obtained in the trials of difetarsone ranging from 81 to $88 \%$ were slightly lower than the 96,96 , and $94 \%$ obtained respectively by Junod (1965), Garin et al. (1970), and Nitzulescu et al. (1970) using 10-day schedules. However, the method of examination of faeces used in the present study was more stringent. There was little difference in the final cure rates after a 10-day dosage schedule or a five-day schedule. It appeared, however, that the five-day schedule took longer to effect a cure in a number of patients than did the 10-day schedule.

Adult worms were observed in only one patient, a child, and these were being passed 12 days after the completion of five days' treatment. It appears that there is little to be gained in re-examining stools earlier than at least two weeks after the completion of treatment. Difetarsone was very well tolerated and no side effects were observed.

Where the infestation is widespread or has been established in the hospital for some time potentially infective eggs will be found contaminating the grounds and buildings for lengthy periods, probably in years. A further point is that patients may be harbouring immature worms which may not be affected by the drug. Hence the design of the initial treatment regimen for the hospital and the timing of subsequent retreatment have to be considered carefully.

The examination of stool specimens from every patient by a concentration technique would be very time-consuming and is not a practical proposition for most hospitals. Sample surveys of wards would give an indication of the incidence in a hospital, and where this is high it is probably reasonable with such a non-toxic drug to treat all of the patients initially. Because of the problem of reinfestation and the treatment failures retreatment appears to be necessary, and treatments at six monthly intervals over a period of five years may be necessary to eliminate the parasite from a heavily infested hospital.

We are grateful to the medical superintendents and consultants of the hospitals involved for their co-operation. We are also grateful to the nursing staff of these hospitals for the collection of the specimens, and to the laboratory staff of the Royal Eastern Counties Hospital for permission to quote some of their findings.

\section{References}

Allen, A. V. H., and Ridley, D. S. (1970). Fournal of Clinical Pathology, 23, Beer, R. J. S. (1971). British Medical fournal, 2, 44.

Boycott, A. E. (1904). Fournal of Hygiene, 4, 437.

Catzel, P. (1966). Paediatric Prescriber, 3rd edn. Oxford, Blackwell Scientific. Financial Times, 1971, 3 August, p. 4.

French, H. S., and Boycott, A. E. (1905). Fournal of Hygiene, 5, 274. Garin, J. P., Despeignes, J., Woehrle, R., and Ambroise-Thomas, P. (1970) Bulletin de la Societe de Pathologie Exotique et de Ses Filiales, 63, 94

Hucker, A. G., and Schofield, F. D. (1956). British Medical fournal, 2, 1159. Junod, C. (1965). Bulletin de la Societe de Pathologie Exotique et de Ses Filiales, 58, 653 .

Manson-Bahr, P. H. (1938). British Encyclopaedia of Medical Practice, vol. 9, p. 133. London, Butterworths.

Ministry of Agriculture, Fisheries and Food (1971). Agricultural Statistics 1968-69. London, H.M.S.O.

Nitzulescu, V. et al. (1970). Bulletin de la Societe de Pathologie Exotique et de Ses Filiales, 63, 251.

Paine, D. H. D., Lower, E. S., and Cooper, T. V. (1960). British Medical Fournal, 1, 770 .

Silverston, N. A. (1962). British Medical fournal, 2, 1726.

Still, G. F. (1927). Common Disorders of Childhood, 5th edn., p. 370 . London, Oxford University Press.

Thompson, R. G., Hutchinson, J. G. P., and Johnston, N. M. (1972). British Medical fournal, 1, 591 .

Today's Drugs (1970). British Medical fournal, 1, 738.

World Health Organization (1964). Technical Report Series, No. 277, p. 65.

\title{
Heart Failure and Neonatal Hypocalcaemia
}

\author{
O. TROUGHTON, S. P. SINGH
}

British Medical fournal, 1972, 4, 76-79

\section{Summary}

Six infants had congestive heart failure for which no cause could be found apart from a low serum calcium. All except one recovered completely and had normal chest $x$-ray appearances and E.C.G.s on discharge from hospital. Necropsy on the infant who died showed engorgement and dilation of the right side of the heart and a small ductus but no other abnormalities. It is suggested that hypocalcaemia should be considered as a possible cause of heart failure in infants, especially when oedema is prominent.

\section{Introduction}

Although calcium plays a major part in the metabolism of the myocardium serious cardiovascular disease due to its de-

Children's Hospital, Birmingham 16

O. TROUGHTON, M.R.C.P., D.C.H., Senior Registrar

S. P. SINGH, M.B., P.R.C.P., Consultant Cardiologist ficiency has been reported only rarely. Hegglin (1939-40) described heart failure associated with hypocalcaemia in a woman aged 51 years. This failed to respond to digitalis and diuretics but improved promptly when she was given AT 10 (dihydrotachysterol). Dodd and Rapoport (1949) stated that cardiac manifestations-oedema, systolic murmurs, change in rate-could occur in hypocalcaemia, though in the presence of the postacidotic state when other electrolyte disturbances were also present. Schulman and Ratner (1955) reported the case of a 12-year-old girl with chronic hypoparathyroidism whose cardiac decompensation improved with rises in serum calcium. The heart was normal three months after treatment. Weill et al. (1967) reported on a 9-year-old child with idiopathic hypoparathyroidism who had cardiac enlargement which regressed over a period of three months on calcium and vitamin $\mathrm{D}$.

So far as infants are concerned actual heart failure has been reported only twice. Edge (1963) described three infants with congestive failure associated with hypocalcaemia, and Najjer et al. (1967) reported the case of an 18-month-old child with rickets and heart failure. We present the cases of six infants who had congestive heart failure for which no cause could be found and in whom the serum calcium was low. The cause of the heart failure was not definitely proved to be hypo- 
calcaemia, but perhaps these cases may stimulate others to investigate hypocalcaemia as a possible cause in the kind of circumstances reported here.

\section{Case Reports}

Case 1.-An Indian boy, small for dates, birth weight $2,500 \mathrm{~g}$ normal delivery, was admitted to hospital at the age of 2 days with generalized oedema, tachypnoea, and central cyanosis. There were no murmurs, the femoral pulses were normal, and the lungs were clear but the liver was palpable $7 \mathrm{~cm}$ below the costal margin Chest $\boldsymbol{x}$-ray examination showed cardiac enlargement with pulmonary congestion (Fig. 1). E.C.G. showed 2:1 atrioventricular block with ventricular extrasystoles and a Q-T interval of $0.6 \mathrm{sec}$. Serum calcium was $4.4 \mathrm{mg} / 100 \mathrm{ml}$, serum phosphorus $12.2 \mathrm{mg} /$ $100 \mathrm{ml}$, serum magnesium $1.8 \mathrm{mg} / 100 \mathrm{ml}$, and blood urea $60 \mathrm{mg} /$ $100 \mathrm{ml}$. Blood count and serum electrolytes were normal, and blood culture was sterile. He was given digoxin, frusemide, and calcium gluconate. The oedema had almost disappeared after two days, when a chest $x$-ray film showed a much smaller heart (Fig. 2) and E.C.G. showed sinus rhythm with ventricular extrasystoles. Serum calcium was $6.5 \mathrm{mg} / 100 \mathrm{ml}$, and four days later it was $9 \mathrm{mg} / 100 \mathrm{ml}$. Although his cardiac status had greatly improved his general condition was unsatisfactory and he developed hyponatraemia with metabolic acidosis. Intravenous glucose and insulin quickly corrected the former, but the latter persisted for five days.

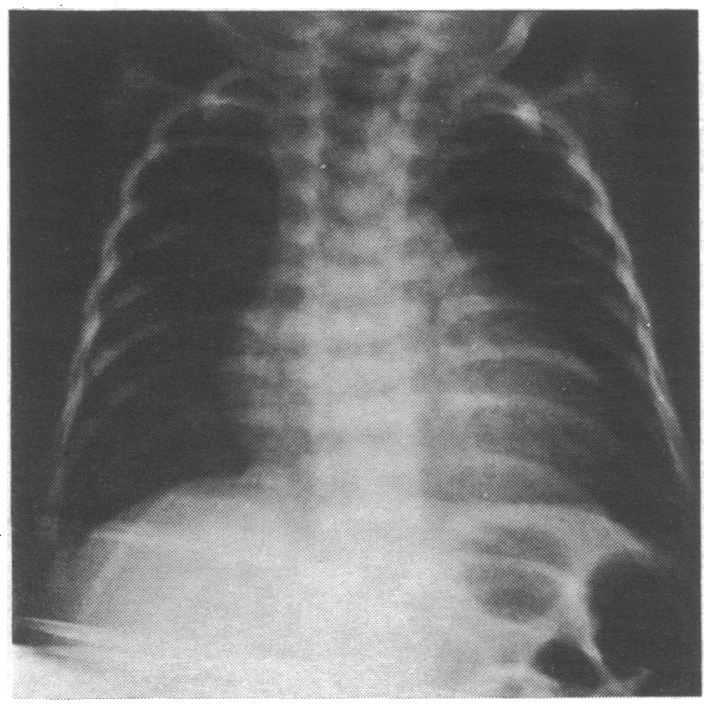

PIG. 1-Case 1. Chest $x$-ray appearances of cardiac enlargement and pulmonary congestion.

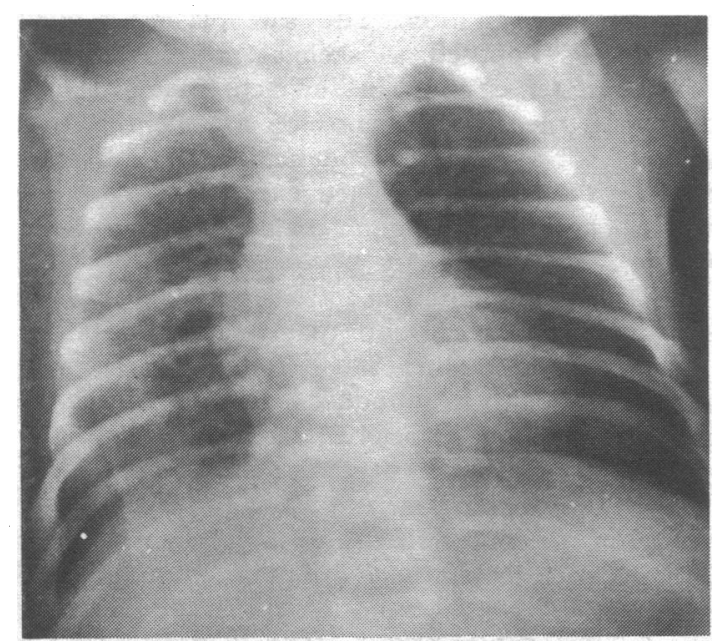

PIG. 2-Case 1. Appearances after two days showing a smaller heart. (Reduction in heart size was greater than shown here since this is a portable $x$-ray film taken more in expiration than Fig. 1.)
Renal tubular acidosis was excluded by ammonium chloride loading. An intravenous pyelogram showed nothing abnormal and the urine remained sterile throughout his stay in hospital. The liver remained enlarged for about three weeks; no reducing substances were found in the urine. On discharge two months later the serum calcium was $9.8 \mathrm{mg} / 100 \mathrm{ml}$ and the blood urea $24 \mathrm{mg} / 100 \mathrm{ml}$. Chest $x$-ray examination and E.C.G. showed no abnormality.

Case 2.-A Caucasian boy, full term, normal delivery, birth weight $3,500 \mathrm{~g}$, was shocked at birth and needed oxygen for three minutes before breathing spontaneously. At seven days he had convulsions, serum calcium was $4.6 \mathrm{mg} / 100 \mathrm{ml}$, and serum phosphorus was $9.6 \mathrm{mg} / 100 \mathrm{ml}$. He was given calcium chloride and occasional convulsions occurred over the next few days. Serum calcium at 12 days was $6.1 \mathrm{mg} / 100 \mathrm{ml}$. At 15 days he began to get breathless on feeding and was transferred to this hospital. There was periorbital oedema and the liver was palpable $4 \mathrm{~cm}$ below the costal margin. The pulse was regular at $160 / \mathrm{min}$. The only other abnormality was a soft systolic murmur down the left sternal edge. Chest $x$-ray examination showed a slightly enlarged heart. A venous angiocardiogram showed a normal main circulatory route with a small flow through a ductus arteriosus. E.C.G. showed low-amplitude T waves in leads I, V5, and V6, with a Q-T interval of 0.28 sec. Serum calcium $5.6 \mathrm{mg} / 100 \mathrm{ml}$, serum phosphorus $8 \mathrm{mg} / 100 \mathrm{ml}$, and serum magnesium $1.2 \mathrm{mg} / 100 \mathrm{ml}$. Blood count and electrolytes were normal. He was given calcium gluconate and digoxin and made good progress. Eight days after admission his chest $x$-ray picture and E.C.G. were normal. Serum calcium was $8.2 \mathrm{mg} / 100 \mathrm{ml}$. He was seen a month and two months later and had remained well with no abnormalities on clinical examination.

Case 3.-Caucasian girl, birth weight 3,000 g. Cyanosis was noted at birth and a tracheo-oesophageal fistula was diagnosed by Lipiodol swallow. Clinical examination was otherwise normal. The fistula was repaired next day. Eighteen hours after operation she was found to have an enlarged liver and peripheral oedema. The respirations were increased and fine crepitations were heard over both lung fields. Clinical examination was otherwise normal. Chest $x$-ray examination showed a slightly enlarged heart. E.C.G. showed low-amplitude $T$ waves in all leads, with a Q-T interval of 0.32 sec. Serum calcium was $7 \cdot 1 \mathrm{mg} / 100 \mathrm{ml}$. Blood count and electrolytes were normal. Treatment consisted of digoxin, frusemide, and calcium gluconate. The oedema began to subside within 24 hours and had disappeared after a few days, and the liver size became normal. At the age of 7 days serum calcium was $8.9 \mathrm{mg} / 100 \mathrm{ml}$. On discharge two weeks later clinical examination, E.C.G., and a chest $x$-ray film showed nothing abnormal.

Case 4.-Caucasian girl, full term, born by elective caesarian section, birth weight $3,600 \mathrm{~g}$. On the day after birth she developed generalized twitching, gross oedema of the legs and abdominal wall, and was breathless. The liver was palpable $4 \mathrm{~cm}$ below the costal margin but there were no other abnormal physical signs. Chest $x$-ray examination showed cardiac enlargement. A venous angiocardiogram showed a normal circulatory route. E.C.G. showed flat $T$ waves in leads $I, V 5$, and V6, with a Q-T interval of 0.4 . Serum calcium was $7 \mathrm{mg} / 100 \mathrm{ml}$, and serum magnesium $1.1 \mathrm{mg} /$ $100 \mathrm{ml}$ (the specimen was haemolysed). Blood count, serum electrolytes and urea, and serum proteins were all normal. Treatment consisted of intravenous magnesium sulphate and calcium gluconate and digoxin. She made good progress, the oedema disappearing over the next seven days, when a chest $x$-ray film showed a normalsized heart, an E.C.G. was normal, and serum calcium was $8.8 \mathrm{mg} /$ $100 \mathrm{ml}$. When seen six weeks later she had made good progress and the chest $x$-ray picture was normal. Serum calcium was $9.3 \mathrm{mg} /$ $100 \mathrm{ml}$.

Case 5.-Caucasion boy, 35 weeks' gestation, normal delivery, birth weight $3,000 \mathrm{~g}$. Exomphalos was present but no other abnormalities were found. Serum calcium was $10.6 \mathrm{mg} / 100 \mathrm{ml}$, blood urea $92 \mathrm{mg} / 100 \mathrm{ml}$, with a raised potassium (capillary specimen obtained with considerable pressure on heel). The exomphalos was repaired the same day, and the next day slight facial oedema was noted and a chest $x$-ray film showed slight pulmonary vascular congestion. The oedema spread to his legs and lower abdomen over the next three days, and chest $x$-ray examination on the fourth postoperative day showed cardiac enlargement and pulmonary vascular congestion (Fig. 3). Serum calcium was $4.6 \mathrm{mg} /$ $100 \mathrm{ml}$, blood urea and electrolytes were normal, and the haemoglobin was $113 \%$. Despite vigorous treatment he died at the age 
Clinical Data on the Six Newborn Infants

\begin{tabular}{|c|c|c|c|c|c|c|}
\hline Case No. & $\begin{array}{l}\text { Age } \\
\text { (Days) } \\
\text { and Sex }\end{array}$ & $\underset{(\mathrm{mg} / 100 \mathrm{ml})}{\text { Serum }}$ & 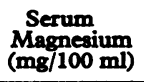 & Heart Rate/Min and Rhythm & $\begin{array}{l}\text { Q-T Interval } \\
\text { in Seconds } \\
\text { (Normal }\end{array}$ & $S-T$ and $T$ Wave Form \\
\hline 1 & $2 \mathrm{M}$ & $4 \cdot 4$ & 一 & Atrioventricular 66, 2:1 A.V. & $0.6(0.36)$ & Normal \\
\hline $\begin{array}{l}2 \\
3 \\
4\end{array}$ & $\begin{array}{l}15 \mathrm{M} . \\
2 \mathrm{~F} . \\
3 \mathrm{~F} .\end{array}$ & $\begin{array}{l}5 \cdot 6 \\
7 \cdot 1 \\
7 \cdot 0\end{array}$ & $\frac{1 \cdot 2}{1 \cdot 1}$ & $\begin{array}{l}170, \text { sinus } \\
110 \text {, sinus } \\
100 \text {, sinus }\end{array}$ & $\begin{array}{l}0.28(0.23) \\
0.32(0.30) \\
0.40(0.30)\end{array}$ & $\begin{array}{l}\text { Low amplitude T waves in leads I, V5, V6 } \\
\text { Low amplitude T waves in all leads } \\
\text { Flattened T wave in leads I, III, V4R, V5, } \\
\text { V6 }\end{array}$ \\
\hline 5 & $4 \mathrm{M}$ & 6.7 & 0.3 & 150 , sinus & $0.32(0.26)$ & Depressed $S-T$ and $T$ waves in $I, I I, I I I$, \\
\hline 6 & $30 \mathrm{M}$. & $5 \cdot 3$ & $1 \cdot 6$ & 150 , sinus & $0.25(0.26)$ & Flat $\mathrm{T}$ waves in leads I, II, III, V5, V6 \\
\hline
\end{tabular}

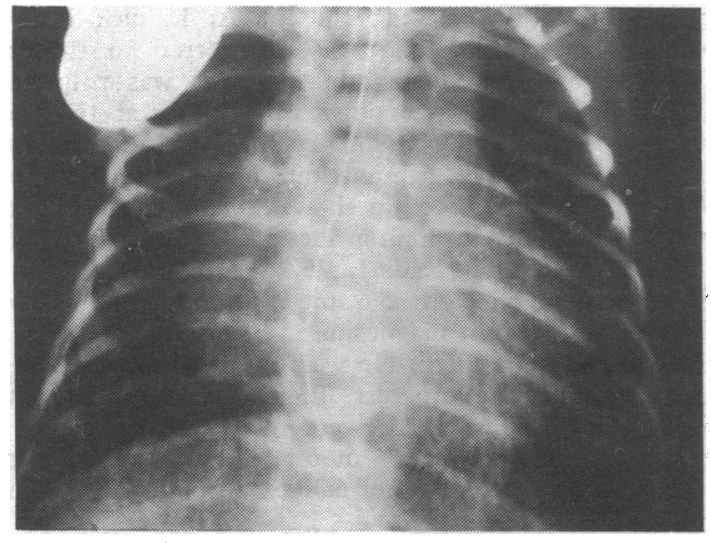

FIG. 3-Case 5. Chest $x$-ray film showing cardiac enlargement and pulmonary vascular congestion.

of 11 days. The day before death his serum calcium was $6.5 \mathrm{mg} /$ $100 \mathrm{ml}$, serum magnesium $0.3 \mathrm{mg} / 100 \mathrm{ml}$, and E.C.G. showed depressed S-T and T waves in leads I, II, III, aVL, and V4 to V6, with a Q-T interval of 0.32 sec. Necropsy showed dilatation and engorgement of the right side of the heart. There were no septal or valvular defects but a small patent ductus was present.

Case 6.-An Indian boy, full term, normal delivery, birth weight $3,100 \mathrm{~g}$, was admitted to hospital at the age of 5 weeks, having had dyspnoea for a week and a convulsion the evening before admission. He was pale and had rapid, grunting respirations. Pulse was regular at $160 / \mathrm{min}$. Temperature $36.5^{\circ} \mathrm{C}$. The liver was palpable $3 \mathrm{~cm}$ below the costal margin. No other abnormalities were found on clinical examination apart from slight periorbital oedema. A chest $x$-ray film (Fig. 4) showed cardiac enlargement with congestive lung changes. E.C.G. showed flat $T$ waves in leads I, II, III, V5, and V6, with a Q-T interval of $0.25 \mathrm{sec}$. Serum calcium was $5.3 \mathrm{mg} / 100 \mathrm{ml}$, phosphorus $6.9 \mathrm{mg} / 100 \mathrm{ml}$, serum

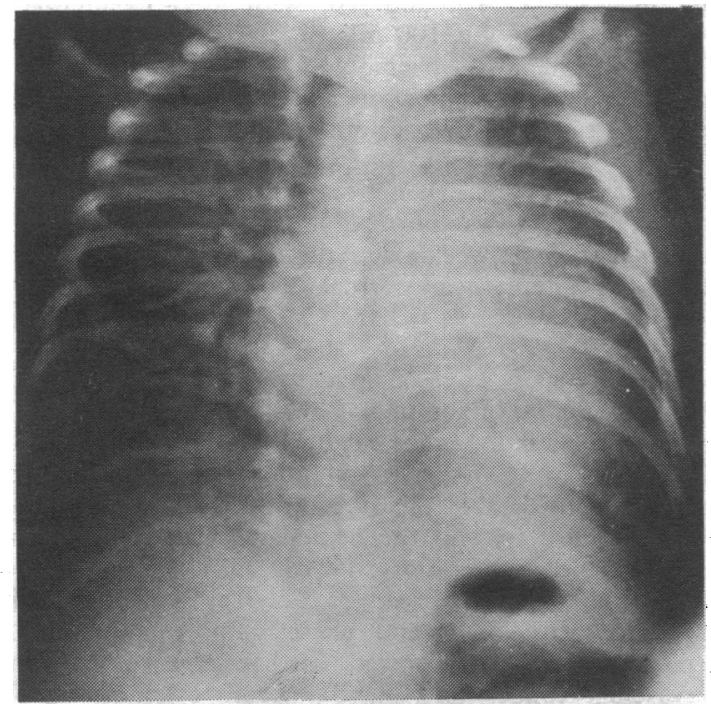

FIG. 4-Case 6. Chest $x$-ray appearances of cardiac enlargement with congestive lung changes. magnesium $1.6 \mathrm{mg} / 100 \mathrm{ml}$, haemoglobin $66 \%$, and serum proteins and electrolytes were normal. He was treated with digoxin, frusemide, calcium gluconate, and ampicillin. Three days later a chest $x$-ray film (Fig. 5) showed almost normal heart size with normal lung fields. Serum calcium was $6.3 \mathrm{mg} / 100 \mathrm{ml}$. He continued to make good progress, although the serum calcium was

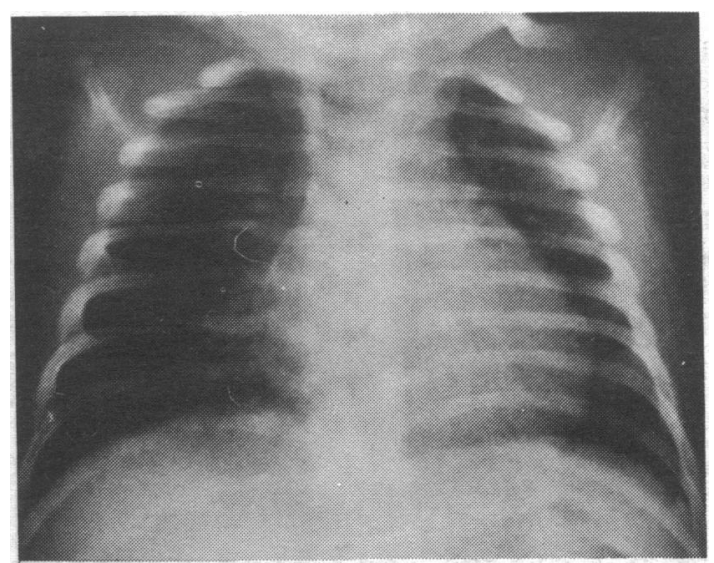

F1G. 5-Case 6. Chest $x$-ray film showing almost normal heart size with normal lung fields.

slow to rise. On discharge six weeks after admission the serum calcium was $8.3 \mathrm{mg} / 100 \mathrm{ml}$, and the chest $x$-ray picture was normal. Ten days later the serum calcium was $9.4 \mathrm{mg} / 100 \mathrm{ml}$ and the E.C.G. was normal.

\section{Discussion}

Calcium is concerned in the "coupling mechanism"-the linking of electrical stimulation to the contractile process-and in the absence of calcium ions contraction does not occur despite electrical excitation. The sarcoplasmic reticulum of heart muscle, as opposed to skeletal muscle, is said to be unable to sequester calcium in sufficient quantities to trigger contraction and therefore depends on extracellular sources of ionic calcium (Sodeman and Sodeman, 1967). Schulman and Ratner (1955) quoted unpublished experiments by Orange on dogs which show that calcium deficiency can cause acute heart failure.

The rarity of heart failure in infants with hypocalcaemia has been explained on the ground that tetany occurs early and results in treatment. Thus Weill et al. (1967) stated that hypocalcaemia must be pronounced and protracted before it produces cardiac manifestations. From the present series, however, it is seen that it need not be protracted, since in only Case 6 could a low serum calcium have been present for a maximum of four weeks, and in four cases the possible maximum duration could have been only four days. Case 4 shows that it need not be pronounced, as the serum calcium was $7 \mathrm{mg} / 100 \mathrm{ml}$. Only three infants had tetany. There are four possibilities: (1) the serum calcium level itself was responsible for the cardiac manifestations; (2) the low serum 
calcium provided the last straw to a myocardium that had been injured by previous factors; (3) the failure was caused by other factors, of which the hypocalcaemia was a byproduct; and (4) the hypocalcaemia was secondary to the heart failure.

It is true that hypocalcaemia of early onset is associated with factors such as a poor Apgar score at one minute, hyaline membrane disease, and sepsis (Tsang and $O h, 1970$ ), which of themselves might cause heart failure. These were not present in this series, however, except that Case 2 was shocked at birth; but he made a prompt recovery and was symptomless for seven days. Acidosis in the neonatal period is said to cause cardiac embarrassment (Rowe and Mehrizi, 1968), but none of the infants was acidotic before the onset of heart failure. Hypoglycaemia has been reported in association with heart failure (Amatayakul et al., 1970; Reid et al., 1971), but blood glucose estimations were performed in three of the present cases and were normal. None of the infants had high haematocrit readings, and none of the mothers were known to have diabetes (Craig, 1958).

With regard to the fourth possibility a low serum albumin is occasionally found secondary to congestive heart failure (Friedberg, 1966), and this would, of course, give rise to a low serum calcium, but this happens only when the failure is chronic. Furthermore, Case 2 was known to have had a low serum calcium for eight days before developing heart failure.

Viral studies were not done in this series, but there was no E.C.G. evidence of myocarditis, and the rapid recovery makes this diagnosis unlikely. There was nothing to suggest myocarditis in the infant that died. In two cases there was a small ductus, but this was not thought large enough to cause heart failure.

Oedema in infant heart failure is usually most prominent around the eyes, whereas in only two of the present babies was this the case. In two it was maximal in the legs, and in the remaining two it was generalized. It is difficult to know how much it was due to heart failure, since oedema in hypocalcaemia has been well documented (Kehrer, 1913; Shannon, 1929; Dodd and Rapoport, 1949; Saville and Kretchmer, 1960; Benson and Parsons, 1964). The mechanism of oedema formation in association with a low serum calcium is not known, but Epstein (1959) suggested that calcium ions play a part in regulating the permeability of the renal tubular epithelium cell membrane, and that a reduction in calcium would result in greater permeability and consequently a decreased ability to reject sodium.

That the low serum calcium was at least instrumental in causing heart failure in the present cases is suggested by the abnormal E.C.G.s, which became normal when the heart failure resolved. The usual effect of a low serum calcium on the E.C.G. is an increase in the Q-T interval due to the prolonged S-T segment. In infants this prolongation was found to be mathematically unrelated to the serum calcium level by Seringe (1960) and Paupe and Berkman (1960), whereas Bechtel (1956), when investigating adults, came to the opposite conclusion. The findings of the first two reports are confirmed in the present cases, and the two infants with relatively high serum calcium levels and relatively prolonged Q-T intervals both had very low serum magnesium levels (Cases 4 and 5). Conceivably hypomagnesaemia was responsible for the clinical picture and the E.C.G. changes; animal experiments suggest that magnesium deficiency can cause heart failure, but this has not been reported in man. The baby reported on by Najier et al. (1967) had a comparatively high serum calcium $(7 \cdot 2 \mathrm{mg} / 100 \mathrm{ml})$.

The effect of a low serum calcium on $T$ waves is controversial; Friedberg (1966) stated that they are normal, while Najjer et al. (1967) claimed that a common abnormality is a sharp, symmetrical, late inversion of the $T$ wave, although not infrequently it is increased in height and may be peaked. Paupe and Berkman (1960) stated that ample, symmetrical, and pointed $T$ waves are well recognized but not constant in hypocalcaemia. We noted flat or depressed $\mathrm{T}$ waves in three cases (see Table).

One of the infants had a 2:1 atrioventricular block with ventricular extrasystoles, illustrating a consequence of hypocalcaemia which has been reported only rarely (Castellanos et al., 1960; Griffin, 1965; Johnson and Jennings, 1968).

We wish to thank Dr. C. G. Parsons and Dr. R. Astley for their help and advice, and also Dr. J. Insley for his sterling work in translating from French into English.

\section{References}

Amatayakul, O., Cumming, G. R., and Haworth, J. C. (1970). Archives of Disease in Childhood, 45, 717

Bechtel, J. T. (1956). Circulation, 13, 837.

Benson, P. F., and Parsons, V. (1964). Quarterly fournal of Medicine, 33, 197. Castellanos, A., De la Torre, H., Azan, L., and Calvino, J. M. (1960). British Heart fournal, 22, 713 .

Craig, W. S. (1958). Pediatrics, 22, 297.

Dodd, K., and Rapoport, S. (1949). American fournal of Diseases of Children, 78, 537.

Edge, W. E. B. (1963). South African Medical fournal, 37, 262.

Epstein, F. H. (1959). Fournal of Chronic Diseases, 11, 255.

Friedberg, C. K. (1966). Diseases of the Heart. 3rd edn., Philadelphia, Saunders.

Griffin, J. H. (1965). American fournal of Diseases of Children, 110, 672.

Hegglin, V. R. (1939-40). Helvetica Medica Acta, 5, 584.

Johnson, J. D., and Jennings, R. (1968). American fournal of Diseases of Children, 115, 373.

Kehrer, E. (1913). Archiv für Gynaekologie, 99, 372.

Naijer, S. S., Nassif, S. I., and Khazen, A. F. (1967). Lebanese Medical fournal, $20,69$.

Paupe, J., and Berkman, M. (1960). Médecine Infantile, 76, 63.

Reid, M. McC., Reilly, B. J., Murdock, A. I., and Swyer, P. R. (1971). Acta Paediatrica Scandinavica, 60, 295.

Rowe, R. D., and Mehrizi, A. (1968). Neonate with Congenital Heart Disease. Philadelphia, Saunders.

Saville, P. D., and Kretchmer, N. (1960). Biologia Neonatorum, 2, 1.

Schulman, J. L., and Ratner, M. (1955). Pediatrics, 16, 848.

Seringe, P. (1960). Annales de Pédiatrie, 7, 606.

Seringe, P. (1960). Annales de Pediatrie, 7, 606.

Sodeman, W. A., and Sodeman, W. A. (1967). Pathologic Physiology, 4th edn., p. 469.

Tsang, R. C., and Oh, W. (1970). Pediatrics, 45, 773.

Weill, J., Bouchard, R., Antebi, L., Guedeney, J., and Perles, C. (1967). Bulletin et Memoires de la Société Médicale des Hópitaux de Paris, 118, 659 . 